\title{
THE INFLUENCE OF AN ISOTHERMAL ANNEALING PROCESS \\ ON THE STRUCTURE AND MAGNETIC PROPERTIES OF THE BULK AMORPHOUS ALLOY FeCoBYMo
}

\author{
VPLIV IZOTERMNEGA ŽARJENJA NA STRUKTURO IN \\ MAGNETNE LASTNOSTI MASIVNE AMORFNE ZLITINE \\ FeCoBYMo
}

\author{
Paweł Pietrusiewicz', Marcin Nabiałek ${ }^{1}$, Jacek Olszewski ${ }^{1}$, Sabina Lesz ${ }^{2}$ \\ ${ }^{1}$ Czestochowa University of Technology, Institute of Physics, 19 Armii Krajowej Av., 42-200 Czestochowa, Poland \\ ${ }^{2}$ Silesian Technical University, Institute of Engineering Materials and Biomaterials, Konarskiego St. 18a, 44-100 Gliwice, Poland \\ pietrusiewicz@wip.pcz.pl, pawelpietrusiewicz@wp.pl \\ Prejem rokopisa - received: 2015-06-30; sprejem za objavo - accepted for publication: 2015-12-24
}

doi: $10.17222 /$ mit.2015.151

\begin{abstract}
This paper presents the results of research into a bulk amorphous alloy based on Fe. Samples with the composition $\mathrm{Fe}_{61} \mathrm{Co}_{10} \mathrm{Y}_{8} \mathrm{Mo}_{1} \mathrm{~B}_{20}$ were prepared in the form of plates using an injection-casting method. The samples were then subjected to an isothermal annealing process (at less than the crystallization temperature) of $700 \mathrm{~K}$ for $1 \mathrm{~h}$ and $770 \mathrm{~K}$ for $3.5 \mathrm{~h}$ The structures of the samples were investigated, both in the state after solidification and following the heat treatment, using X-ray diffraction (XRD) and Mössbauer spectroscopy. The results confirmed that the samples, both after solidification and after annealing, were amorphous. Magnetic measurements were carried out using a vibrating-sample magnetometer (VSM) with magnetic fields of up to $2 \mathrm{~T}$. Based on these measurements, the effect of the isothermal annealing process on the magnetic properties was defined, including the saturation magnetization $\mu_{0} M_{\mathrm{s}}$ and coercive field $\mathrm{H}_{\mathrm{c}}$. Using the Kronmüller theory, the initial magnetization curves were analysed in the area of approach to ferromagnetic saturation. On the basis of this theory, the quantity and quality of the structural defects were defined; these defects play a critical role in the magnetization process in high magnetic fields. Following this study, the sample annealed at $770 \mathrm{~K}$ for $1 \mathrm{~h}$ was found to feature a relatively low coercive field and the higher value of magnetization saturation. Linear defects, the so-called quasidislocational dipoles, played the leading role in the process of magnetization of the test samples.
\end{abstract}

Keywords: bulk amorphous alloys, structure, soft magnetic properties, defects

Članek predstavlja rezultate raziskave masivne amorfne zlitine na osnovi Fe. Vzorci s sestavo $\mathrm{Fe}_{61} \mathrm{Co}_{10} \mathrm{Y}_{8} \mathrm{Mo}_{1} \mathrm{~B}_{20}$ so bili pripravljeni v obliki plošč, s pomočjo tlačnega litja. Vzorci so bili izotermno žarjeni $1 \mathrm{~h}$ (pri temperaturi nižji od temperature kristalizacije) na $700 \mathrm{~K}$ in $3,5 \mathrm{~h}$ na $770 \mathrm{~K}$. Preiskana je bila struktura vzorcev, v stanju po strjevanju in po toplotni obdelavi. Uporabljena je bila rentgenska difrakcija (XRD) in Mössbauerjeva spektroskopija. Rezultati so potrdili, da so bili vzorci po strjevanju in po žarjenju $\mathrm{V}$ amorfnem stanju. Magnetne meritve so bile izvedene s pomočjo magnetometra $\mathrm{z}$ vibriranjem vzorca (VSM) v magnetnih poljih jakosti do $2 \mathrm{~T}$. Na osnovi meritev je bil določen vpliv izotermnega žarjenja na magnetne lastnosti, vključno z nasičeno magnetizacijo $\mu_{0} M_{\mathrm{s}}$ in koercitivnim poljem $H_{\mathrm{c}}$. Z uporabo Kronmüllerjeve teorije so bile analizirane začetne krivulje magnetizacije blizu področja feromagnetnega nasičenja. Na osnovi te teorije je bila določena količina in kakovost strukturnih napak; te napake igrajo ključno vlogo pri procesu magnetizacije v močnih magnetnih poljih. Na podlagi te študije je bilo ugotovljeno, da vzorci žarjeni $1 \mathrm{~h}$ kažejo relativno šibko koercitivno polje in visoko vrednost nasičene magnetizacije. Linearne napake, imenovane kvazi-dislokacijski dipoli, igrajo vodilno vlogo pri procesu magnetizacije preizkušanih vzorcev.

Ključne besede: masivne amorfne zlitine, struktura, mehko magnetne lastnosti, napake

\section{INTRODUCTION}

Amorphous soft magnetic materials are investigated in many research centres around the world. These materials are characterized by a low coercive field and high saturation magnetization. ${ }^{1-3}$ From a thermodynamic point of view, the structure of these materials is metastable. Nevertheless, such materials can be applied in devices such as electronic measuring and surveillance systems, magnetic wires, magnetic sensors, band-pass filters, magnetic shielding, energy-saving electric power transformers and other applications. ${ }^{4,5}$ During the past 20 years, intensive research has been conducted on amorphous alloy groups having a thickness or diameter exceeding $100 \mu \mathrm{m}$; these are called bulk metallic glasses
(BMGs). ${ }^{6,7}$ These materials have good soft magnetic properties and a high mechanical strength. ${ }^{8}$

As mentioned previously, rapidly cooled amorphous materials are thermodynamically unstable; they exhibit instability in their physical properties with respect to time and temperature. In general, their thermodynamic stability can be improved by annealing for a specified time at appropriate temperatures. ${ }^{9-12}$

As shown in the literature, the magnetic properties of amorphous alloys depend strongly on the annealing temperature. ${ }^{13-16}$ During the earlier sample production process, free volumes are created; annealing the samples at low temperatures leads to the diffusion of these free volumes to the surface of the material. Thus, the soft magnetic properties of these alloys can be improved 
through the relaxation of internal stress, by annealing them at less than the crystallization temperature. ${ }^{17}$

The paper presents results of structural and magnetic studies concerning plate-shaped samples of the bulk amorphous alloy $\mathrm{Fe}_{61} \mathrm{Co}_{10} \mathrm{Y}_{8} \mathrm{Mo}_{1} \mathrm{~B}_{20}$. The investigated material was subjected to two-stage annealing processes, below the crystallization temperature.

\section{EXPERIMENTAL PART}

Samples of the composition $\mathrm{Fe}_{61} \mathrm{Co}_{10} \mathrm{Y}_{8} \mathrm{Mo}_{1} \mathrm{~B}_{20}$ were prepared in the form of plates using an injection-casting method. These amorphous plates featured the following dimensions: $10 \mathrm{~mm}$ width and $0.5 \mathrm{~mm}$ thickness. The component chemicals, used in the production process, were of high purity ( $\sim 99.99 \%)$. The ingots of alloy were melted in an electric arc furnace. The crystalline ingot and amorphous plate samples were prepared under a protective atmosphere of argon. The isothermal annealing of the material samples took place in a vacuum furnace, in order to prevent oxidation processes. Initially, a plate sample was annealed at $700 \mathrm{~K}$ for $1 \mathrm{~h}$ and then at $770 \mathrm{~K}$ for $3.5 \mathrm{~h}$. The structure of the investigated material in the form of a plate, in the state following solidification and after annealing, was examined using a Bruker X-ray diffractometer (XRD) equipped with a copper lamp featuring a characteristic $\mathrm{Cu}-K_{\alpha}$ radiation of wavelength $\lambda=0.154056 \mathrm{~nm}$. The XRD studies were performed within the angular range from $20^{\circ}$ to $120^{\circ}$ with a step of $0.01^{\circ}$ and an exposure time of $7 \mathrm{~s}$. In order to confirm the amorphous structure of the examined samples, Mössbauer spectra were recorded using a Polon spectrometer equipped with a ${ }^{57} \mathrm{Co}$ source with an intensity of $50 \mathrm{mCi}$.

Static hysteresis loops were obtained using a LakeShore vibrating-sample magnetometer (VSM) operating in a magnetic field of up to $2 \mathrm{~T}$. On the basis of these measurements, the magnetization saturation $\left(\mu_{0} M_{s}\right)$ and coercive field $\left(H_{c}\right)$ were determined, both for the heattreated samples and in the state following solidification.

Analysis of the initial magnetization curve was performed in the area of the approach to ferromagnetic saturation, according to the Kronmüller theory. ${ }^{18}$ On the basis of this theory the authors specified the quantity and quality of structural defects playing a decisive role in the

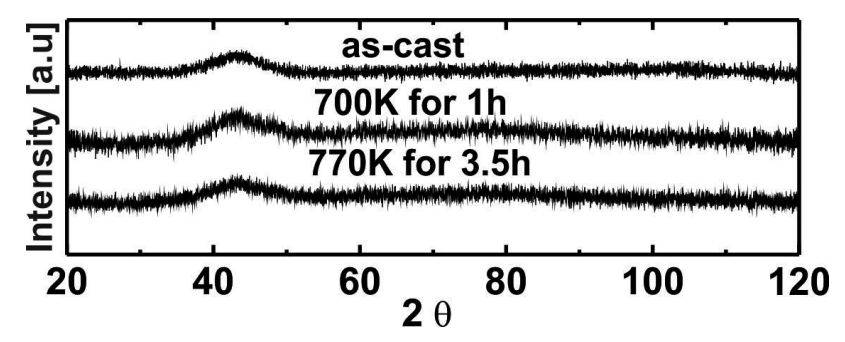

Figure 1: X-ray diffraction patterns for powdered as-quenched, annealed at $700 \mathrm{~K} / 1 \mathrm{~h}$ and $770 \mathrm{~K} / 3.5 \mathrm{~h}$, plates

Slika 1: Rentgenogram zdrobljenih plošč, gašenih ter žarjenih $1 \mathrm{~h}$ na $700 \mathrm{~K}$ in $3,5 \mathrm{~h}$ na $770 \mathrm{~K}$ process of magnetization under the influence of strong magnetic fields.

\section{RESULTS AND DISCUSSION}

Figure 1 shows the X-ray diffraction (XRD) patterns of the $\mathrm{Fe}_{61} \mathrm{Co}_{10} \mathrm{Y}_{8} \mathrm{Mo}_{1} \mathrm{~B}_{20}$ alloy in the states following solidification and after annealing at two different temperatures.

The X-ray diffraction patterns, shown in Figure 1, feature only one broad, blurred, maximum. This kind of maximum occurs for the samples in the state following solidification and after the isothermal annealing process. These patterns are typical for materials featuring an amorphous structure.

Figure 2 shows transmission Mössbauer spectra of the amorphous $\mathrm{Fe}_{61} \mathrm{Co}_{10} \mathrm{Y}_{8} \mathrm{Mo}_{1} \mathrm{~B}_{20}$ alloy plate samples in the state following solidification and after annealing firstly at a temperature of $700 \mathrm{~K}$ for $1 \mathrm{~h}$ and next at $770 \mathrm{~K}$ for $3.5 \mathrm{~h}$. The spectra are expanded due to the disorder of the atomic structure and small asymmetries. The shapes of these spectra are typical for magnetic alloys having an amorphous structure. ${ }^{19,20}$

Hyperfine field distributions $\mathrm{P}(\mathrm{B})$, obtained from analysis of the Mössbauer spectra for all samples of the $\mathrm{Fe}_{61} \mathrm{Co}_{10} \mathrm{Y}_{8} \mathrm{Mo}_{1} \mathrm{~B}_{20}$ alloy (in the state following solidification and after annealing), are shown in Figure 3. These distributions are composed of two maxima. First, the lower maximum $B_{\text {ef }}$ (of the average hyperfine field) is in the $10 \mathrm{~T}$ field, and the second peak lies higher in the $23 \mathrm{~T}$ field. It is assumed that the first low-field peak is associated with the nearest neighbourhoods of $\mathrm{Fe}$ and the local presence of $\mathrm{Y}^{21}$ The second peak corresponds to the areas with less $\mathrm{Fe}$, in which the ${ }^{57} \mathrm{Fe}$ are partly

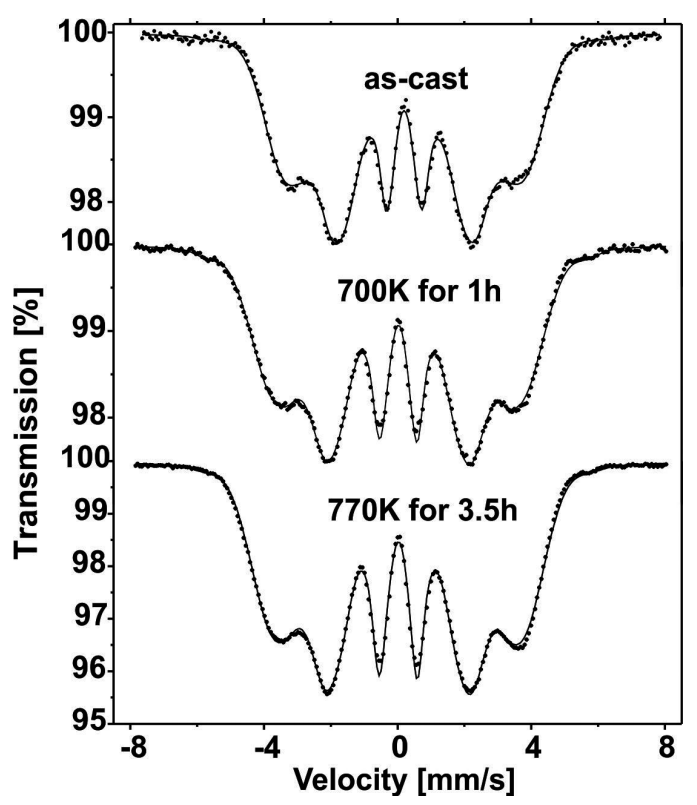

Figure 2: The transmission Mössbauer spectra for the investigated samples

Slika 2: Prenos Mössbauerjevega spektra preiskovanih vzorcev 


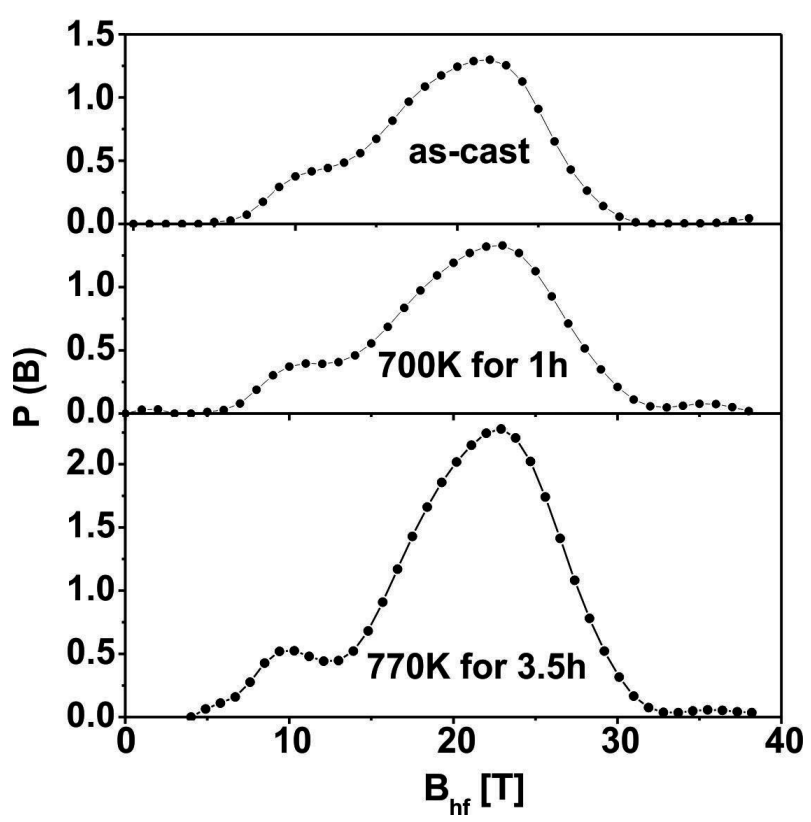

Figure 3: The hyperfine field distribution on the $57 \mathrm{Fe}$ nuclei derived from analysis of the transmission Mössbauer spectra (Figure 2) for the investigated samples of $\mathrm{Fe}_{61} \mathrm{Co}_{10} \mathrm{Y}_{8} \mathrm{Mo}_{1} \mathrm{~B}_{20}$ alloy

Slika 3: Hiper drobna razporeditev polja na 57Fe nukleusu, pridobljena iz analize prenosa Mössbauerjevega spektra (Slika 2) pri preiskovanih vzorcih zlitine $\mathrm{Fe}_{61} \mathrm{Co}_{10} \mathrm{Y}_{8} \mathrm{Mo}_{1} \mathrm{~B}_{20}$

surrounded by magnetic atoms (Co) and partly by non-magnetic atoms (B, Mo).

From an analysis of Figure 3, it can be concluded that post-production thermal treatment led to segregation and the emergence of areas more or less rich in iron. The data obtained from an analysis of the Mössbauer spectra are summarized in Table $\mathbf{1}$.

Figure 4 shows the static magnetic hysteresis loops for the samples in the state following solidification and after heat treatment at different temperatures. These hysteresis loops have a shape typical of materials with

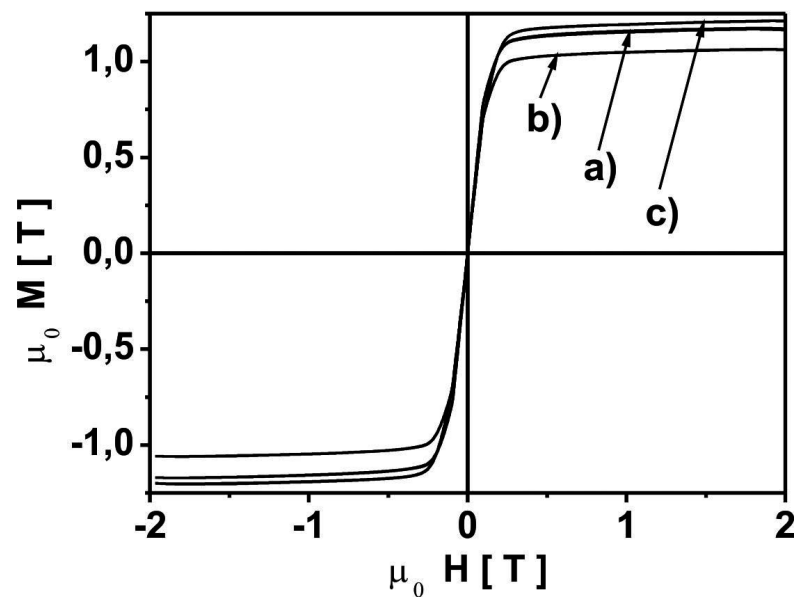

Figure 4: Static hysteresis loops measured for tested samples in the state following solidification (a), annealed at $700 \mathrm{~K} / 1 \mathrm{~h}$ (b) and annealed at $770 \mathrm{~K} / 3.5 \mathrm{~h}$ (c)

Slika 4: Statične histerezne zanke izmerjene na vzorcih v stanju po strjevanju (a), žarjeno $1 \mathrm{~h}$ na $700 \mathrm{~K}$, (b) žarjeno $3,5 \mathrm{~h}$ na $770 \mathrm{~K}$ (c) soft magnetic properties. The data obtained from analysis of the static hysteresis loops, such as the saturation magnetization $\left(\mu_{0} M_{s}\right)$ and the coercive field $\left(H_{c}\right)$, are shown in Table 1.

Table 1: Data from analysis of the static hysteresis loops: $\mu_{0} M_{\mathrm{S}}-$ magnetization, $H_{\mathrm{c}}-$ coercivity and the value of the mean hyperfine field using the ${ }^{57} \mathrm{Fe}$ nuclei $\left(B_{\mathrm{ef}}\right)$ and the dispersion of the hyperfine field distributions of the amorphous phase $\left(D_{\mathrm{am}}\right)$.

Tabela 1: Podatki iz analize statične histerezne zanke: $\mu_{0} M_{\mathrm{S}}-$ magnetizacija, $H_{\mathrm{c}}-$ koercitivnost in vrednost glavnega hiper šibkega polja z uporabo ${ }^{57} \mathrm{Fe}$ nukleusov $\left(B_{\text {ef }}\right)$ in disperzijo razporeditve hiper finega polja amorfne faze $\left(D_{\mathrm{am}}\right)$.

\begin{tabular}{|c|c|c|c|c|}
\hline Sample & $\mu_{0} M_{\mathrm{s}}$ & $H_{\mathrm{c}}$ & $B_{\text {ef }}(\mathrm{T})$ & $D_{\mathrm{am}}(\mathrm{T})$ \\
\hline as-cast & 1.17 & 42 & $19.50(6)$ & $5.13(8)$ \\
\hline 700 & 1.05 & 27 & $20.57(5)$ & $5.78(5)$ \\
\hline 770 & 1.20 & 37 & $20.78(4)$ & $5.50(5)$ \\
\hline
\end{tabular}

The initial magnetization curves were analysed according to the theory of the approach to ferromagnetic saturation proposed by $\mathrm{H}$. Kronmüller and M. Fähnle ${ }^{18}$, A. Neuweiler et al. ${ }^{22}$ and M. Hirsher et al. ${ }^{23}$ This theory facilitates the extraction of information about the sources of internal stresses occurring in the material, such as free volumes and quasi-dislocation dipoles. ${ }^{18,22}$ Inhomogeneities affect the internal stress of the structure and the process of magnetization in high magnetic fields. An analysis of the initial magnetization curves enabled the determination of the type of defects in the samples in a state following solidification and after isothermal annealing at the temperatures of $700 \mathrm{~K}$ and $770 \mathrm{~K}$. Figure 5 shows a 'linear-fit' for the sample following solidification, fulfilling the law of the approach to ferromagnetic saturation (LAFS) as a function of $\left(\mu_{0} H\right)^{-1}$ within magnetic fields ranging from $0.016 \mathrm{~T}<\mu_{0} H<$ $0.74 \mathrm{~T}$. In contrast, for the sample after the isothermal

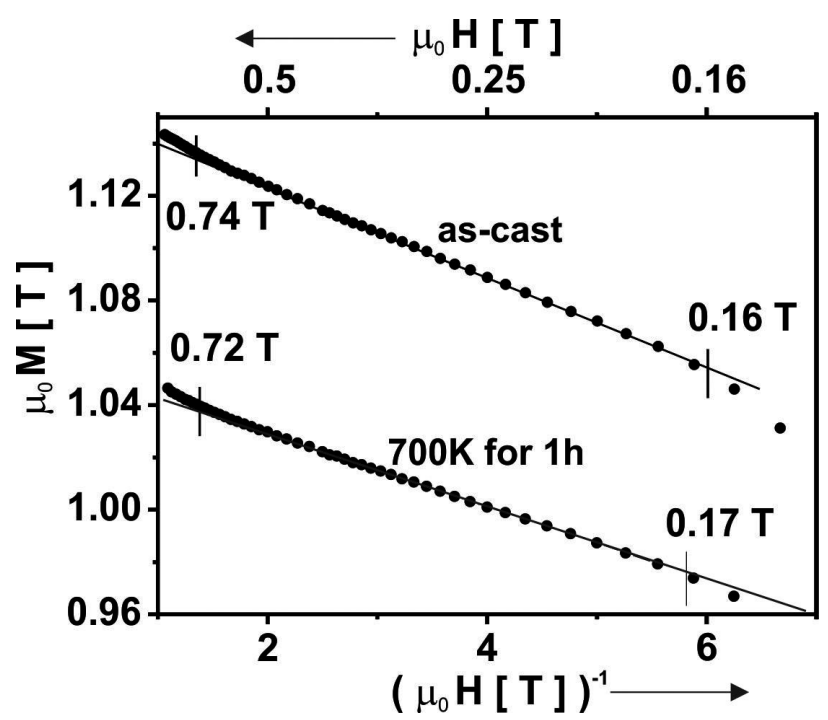

Figure 5: Magnetization as a function of $\left(\mu_{0} H\right)^{-1}$ for a sample after solidification and annealed at $700 \mathrm{~K}$ for $1 \mathrm{~h}$

Slika 5: Magnetizacija v odvisnosti od $\left(\mu_{0} H\right)^{-1}$ za vzorec po strjevanju in žarjenem $1 \mathrm{~h}$ na $700 \mathrm{~K}$ 


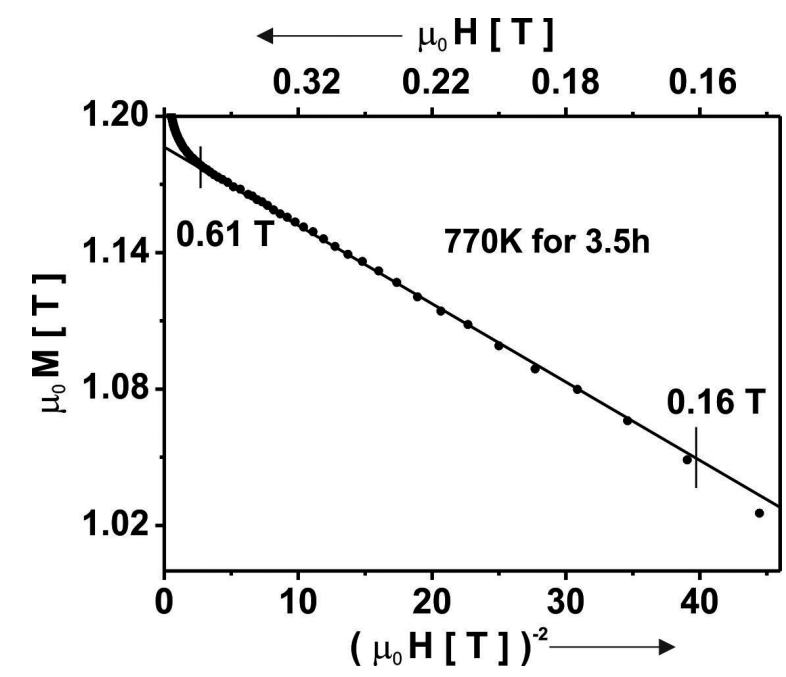

Figure 6: Magnetization as a function of $\left(\mu_{0} H\right)^{-1}$ for a sample after annealing at $770 \mathrm{~K}$ for $3.5 \mathrm{~h}$

Slika 6: Magnetizacija v odvisnosti od $\left(\mu_{0} H\right)^{-1}$ pri vzorcu žarjenem 3,5 h na $770 \mathrm{~K}$

annealing process, at a temperature of $700 \mathrm{~K}$ for $1 \mathrm{~h}$ the LAFS was fulfilled within the range of magnetic field of $0.017 \mathrm{~T}<\mu_{0} H<0.72 \mathrm{~T}$. This indicates that defects in the form of quasi-dislocational dipoles are playing a decisive role in the magnetization process (where the exchange distance $l_{H}$ it is greater than the size of the dipole defect $\left.D_{\text {dip }}\left(l_{\mathrm{H}}>D_{\text {dip }}\right)\right) .{ }^{18,22}$ For the sample annealed at $770 \mathrm{~K}$ for $3.5 \mathrm{~h}$, the LAFS was fulfilled as a function of $\left(\mu_{0} H\right)^{-2}$ (Figure 6) within the range from $0.16 \mathrm{~T}<\mu_{0} H<0.61 \mathrm{~T}$. In this case, the decisive role in the process of magnetization is played by quasi-dislocational dipoles, for which there is a relation $l_{\mathrm{H}}<\mathrm{D}_{\mathrm{dip}}$.

At higher fields, where structural defects did not play a significant role in the magnetization process, the magnetization of the material occurs by means of the damping of thermally induced magnetic spin waves.

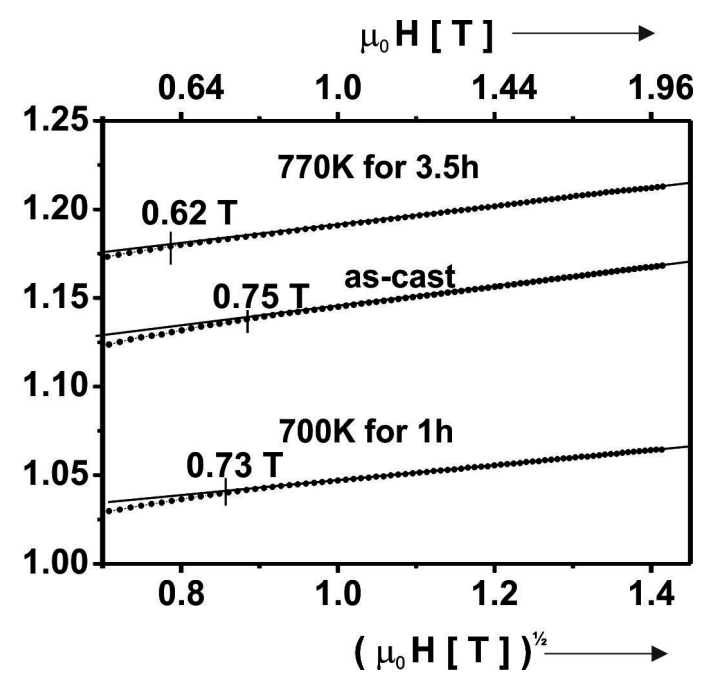

Figure 7: The Holstein-Primakoff para-process obtained for the investigated alloy

Slika 7: Holstein-Primakoff paraproces pridobljen za preiskovano zlitino
Figure 7 shows the linear fit of the magnetization as a function of $\left(\mu_{0} H\right)^{1 / 2}$, describing the Holstein-Primakoff paraprocess. ${ }^{24}$ The following relationship was used in Equation (1):

$$
b=3.54 g \mu_{0} \mu_{\mathrm{B}}\left(\frac{1}{4 \pi D_{s p f}}\right)^{3 / 2} k T\left(g \mu_{\mathrm{B}}\right)^{1 / 2}
$$

where $k$ - Boltzmann constant, $\mu_{B}$ - Bohr's magneton, $g$ - gyromagnetic coefficient, calculated spin wave stiffness parameter $\left(D_{\text {spf }}\right){ }^{20}$ The calculated data, based on the theory of approach to ferromagnetic saturation, is summarized in Table 2.

Based on analysis of the data, presented in Table 2, and in the papers ${ }^{20,25,26}$, it can be concluded that the sample that was thermally treated at $700 \mathrm{~K}$ for $1 \mathrm{~h}$ featured the most relaxed and homogeneous structure; this can also be seen through an analysis of the results of the magnetic and Mössbauer studies, presented in Table $\mathbf{1 .}$

Table 2: Data obtained from analysis of the magnetization as a function of the magnetic field, as powers of $1 / 2,1,2$ and $1 / 2 . D_{\text {spf }}-$ spin wave stiffness parameter, $A_{\mathrm{ex}}-$ exchange constant, $l_{\mathrm{h}}$ - exchange length, $N_{\text {dip }}$ - density of quasi-dislocational dipoles (1) as-cast state, (2) annealed $700 \mathrm{~K}$, (3) annealed $770 \mathrm{~K}$

Tabela 2: Podatki dobljeni iz analize magnetizacije, v odvisnosti od magnetnega polja, v pristojnosti $1 / 2,1,2$ in $1 / 2 . D_{\text {spf }}$ - parameter togosti spinskega vala, $A_{\mathrm{ex}}$ - izmenjalna konstanta, $l_{\mathrm{h}}$ - dolžina izmenjave, $N_{\text {dip }}$ - gostota kvazi-dislokacijskih dipolov (1) lito stanje, (2) žarjeno na $700 \mathrm{~K}$, (3) žarjeno na $770 \mathrm{~K}$

\begin{tabular}{|c|c|c|c|c|c|}
\hline lp & $\begin{array}{c}B \\
\left(10^{-2} \mathrm{~T}^{1 / 2}\right)\end{array}$ & $\begin{array}{c}D_{\text {spf }} \\
\left(10^{-2}\right. \\
\left.\mathrm{meV} \mathrm{nm}^{2}\right)\end{array}$ & $\begin{array}{c}A_{\text {ex }} \\
\left(10^{-12}\right. \\
\left.\mathrm{J} \mathrm{m}^{-1}\right)\end{array}$ & $\begin{array}{c}l_{\mathrm{h}} \\
\left(10^{-9} \mathrm{~nm}\right)\end{array}$ & $\begin{array}{c}N_{\text {dip }} \\
\left(10^{16}\right. \\
\left.\mathrm{nm}^{-2}\right)\end{array}$ \\
\hline 1 & $5.657(6)$ & $45.11(6)$ & $1.71(3)$ & $2.24(3)$ & $19.93(3)$ \\
\hline 2 & $4.333(2)$ & $53.84(2)$ & $1.86(3)$ & $2.38(3)$ & $17.61(3)$ \\
\hline 3 & $5.415(2)$ & $46.41(2)$ & $1.80(2)$ & $2.48(2)$ & $16.24(2)$ \\
\hline
\end{tabular}

\section{CONCLUSIONS}

In the case of crystalline materials, it is well known that the structure is well described and can by characterised by one primitive cell featuring a certain number of atoms and angular translation. However, in the case of amorphous materials, their structure hitherto has not been completely characterised. In general, in the literature an amorphous structure is described as a metastable system of randomly distributed atoms. The first sign of changes in this structure is the process of nucleation of the crystalline grains, which results in a material consisting of two phases: the amorphous matrix and the fine crystalline grains. Of course, the results of the investigations concerning amorphous materials that have been subjected to an annealing process (below the crystallisation temperature) are presented in many papers. However, the description of the changes in the magnetic parameters is limited only to changes in the exchange interactions between the magnetic atoms.

In this paper, the "real" structure of an amorphous alloy in the as-quenched state, and after two stages of the 
isothermal annealing, has been studied. An indirect method of investigation has been used, which relies on an analysis of the initial magnetization curves in the LAFS region. ${ }^{18,27}$ Currently, this is the only known method which facilitates a determination of the type and volume of the structural defects present in the amorphous materials. These defects are the source of the short-range structural defects and lead to non-collinear distributions of the magnetisation in their vicinity, which is directly reflected in the changes to the magnetisation curve.

It is well known that annealing results in structural relaxation. This can happen in two-ways: by conglomerating the free volumes to the linear defects or by releasing free volumes to the surface. Therefore, a two-stage annealing process was performed, at well-below the crystallisation temperature (at $700 \mathrm{~K}$ and $770 \mathrm{~K}$ ). This resulted in structural relaxation through changes in the density and the local chemical composition, leading to a decrease in the number of centres of relaxation. It is shown in the literature ${ }^{14,28-31}$ that relaxations occur at the atomic level, where the pre-exponential factor in the Arrhenius law is in the order of $10^{-15}$.

The investigated plate-shaped samples of the $\mathrm{Fe}_{61} \mathrm{Co}_{10} \mathrm{Y}_{8} \mathrm{Mo}_{1} \mathrm{~B}_{20}$ alloy in the state following solidification and after annealing at temperatures of $700 \mathrm{~K}$ and $770 \mathrm{~K}$ were found to feature an amorphous structure.

The magnetic studies showed that the annealing temperature has a significant impact on the changes in the magnetic properties. It was found that the sample annealed at $700 \mathrm{~K}$ for 1 had the lowest coercive field, $H_{\mathrm{c}}=27 \mathrm{~A} / \mathrm{m}$. In contrast, the sample that was heattreated at $770 \mathrm{~K}$ for $3.5 \mathrm{~h}$ had the highest saturation magnetization.

The results of the Mössbauer studies and the analysis of the initial magnetization curve, in accordance with Kronmüller theory, showed that thermal treatment at a temperature of $700 \mathrm{~K}$ for $1 \mathrm{~h}$ caused the greatest homogenization of the structure of the samples. On the other hand, for the investigated alloy in the form of plates annealed at $700 \mathrm{~K}$ for $1 \mathrm{~h}$, the decisive role in the process of magnetization is played by defects in the form of quasi-dislocational dipoles for which the relationship $l_{\mathrm{H}}>D_{\text {dip }}$ is satisfied. For the plate samples that were annealed at $770 \mathrm{~K}$ for $3.5 \mathrm{~h}$, the decisive role in the process of magnetization is played by quasi-dislocational dipoles for which there is a relationship $l_{\mathrm{H}}<\mathrm{D}_{\text {dip. }}$.

\section{REFERENCES}

${ }^{1}$ P. Pietrusiewicz, M. Nabialek, M. Szota, K. Perduta, Microstructure and soft magnetic properties of $\mathrm{Fe}_{61} \mathrm{Co}_{10} \mathrm{Y}_{8} \mathrm{Me}_{1} \mathrm{~B}_{20}$ (where $\mathrm{Me}=\mathrm{W}$, $\mathrm{Zr}$ or $\mathrm{Nb}$ ) amorphous alloys, Archives of Metallurgy and Materials, 57 (2013) 1, 265-270, doi:10.2478/v10172-012-0021-8

${ }^{2}$ P. Pietrusiewicz, M. Nabiałek, M. Dośpiał, K. Gruszka, K. Błoch, J. Gondro, P. Bragiel, M. Szota, Z. Stradomski, Influence of production method on the magnetic parameters and structure of $\mathrm{Fe}_{61} \mathrm{Co}_{10} \mathrm{Y}_{8} \mathrm{Nb}_{1} \mathrm{~B}_{20}$ amorphous alloys in the as-quenched state, Journal of Alloys and Compounds, 615 (2014), S67-S70, doi:10.1016/j.jallcom.2014.03.028
${ }^{3}$ S. Lesz, M. Nabiałek, R. Nowosielski, Structural, thermal and magnetic properties of Fe-Co-Ni-B-Si-Nb bulk amorphous alloy, Mater. Tehnol., 49 (2015) 3, 409-412, doi:10.17222/mit.2014.108

${ }^{4}$ R. Hasegawa, Advances in amorphous and nanostructured materials, Journal of Optoelectronics and Advanced Materials, 6 (2004) 2, 503-510

${ }^{5}$ M. Vazquez, Soft magnetic wires, Physica B, 299 (2001) 3-4, 302-313, doi:10.1016/S0921-4526(01)00482-3

${ }^{6}$ W.H. Wang, C. Dong, C.H. Shek, Bulk metallic glasses, Materials Science and Engineering R, 44 (2004), 45-89, doi:10.1016/ j.mser.2004.03.001

${ }^{7}$ C. Suryanarayana, A. Inoue, Iron-based bulk metallic glasses, International Materials Reviews, 58 (2013) 3, 131-166, doi:10.1179/ 1743280412Y.0000000007

${ }^{8}$ A. Inoue, B. L. Shen, A new Fe-based bulk glassy alloy with outstanding mechanical properties, Advanced Materials, 16 (2004) 23-24, 2189-2192, doi:10.1002/adma.200400301

${ }^{9} \mathrm{~T}$. Sahoo, Influence of annealing environment on microstructure and magnetic properties of amorphous $\mathrm{Co}_{75} \mathrm{Fe}_{5} \mathrm{Zr}_{10} \mathrm{~B}_{10}$ ribbons, Journal of Alloys and Compounds, 470 (2009) 1-2, 16-19, doi:10.1016/ j.jallcom.2008.02.088

${ }^{10} \mathrm{M}$. Nabiałek, Soft magnetic and microstructural investigation in Fe-based amorphous alloy Journal of Alloys and Compounds, 642 (2015), 98-103, doi:10.1016/j.jallcom.2015.03.250

${ }^{11}$ K. M. Gruszka, M. Nabiałek, K. Błoch, J. Olszewski, Effect of heat treatment on the shape of the hyperfine field induction distributions and magnetic properties of amorphous soft magnetic $\mathrm{Fe}_{62} \mathrm{Co}_{10} \mathrm{Y}_{8} \mathrm{~B}_{20}$ alloy, Nukleonika, 60 (2015) 1, 23-27, doi:10.1515/nuka-2015-0007

${ }^{12}$ K. Gruszka, M. Nabiałek, K. Błoch, S. Walters, Analysis of the structure (XRD) and microstructure (TEM, SEM, AFM) of bulk amorphous and nanocrystalline alloys based on $\mathrm{FeCoB}$, International Journal of Materials Research (formerly Z. Metallkd.), 106 (2015) 7, 689-696, doi 10.3139/146.111226

${ }^{13}$ J. L. Fu, Z. J. Yan, Y. Xu, X. L. Fan, D.S. Xue, Effects of annealing temperature on structure and magnetic properties of amorphous $\mathrm{Fe}_{61} \mathrm{Co}_{27} \mathrm{P}_{12}$ nanowire arrays, Journal of Physics and Chemistry of Solids, 68 (2007) 12, 2221-2226, doi:10.1016/j.jpcs.2007.06.023

${ }^{14}$ M. Nabiałek, P. Pietrusiewicz, K. Błoch, M. Szota, An investigation into the effect of isothermal annealing on the structure (XRD), microstructure (SEM, TEM) and magnetic properties of amorphous ribbons and bulk amorphous plates, International Journal of Materials Research (formerly Z. Metallkd.), 106 (2015) 7, 682-688, doi 10.3139/146.111231

${ }^{15}$ M. Coisson, S.N. Kane, P. Tiberto, F. Vinai, Influence of DC Jouleheating treatment on magnetoimpedance effect in amorphous $\mathrm{Co}_{64} \mathrm{Fe}_{21} \mathrm{~B}_{15}$ alloy, Journal of Magnetism and Magnetic Materials, 271 (2004), 312-317, doi:10.1016/j.jmmm.2003.09.038

${ }^{16}$ S. N. Kane, A. Gupta, S. D. Sarabhai, L. Kraus, Influence of Co content on structural and magnetic properties of $\mathrm{Co}_{\mathrm{x}} \mathrm{Fe}_{84-\mathrm{x}} \mathrm{Nb}_{7} \mathrm{~B}_{9}$ alloys, Journal of Magnetism and Magnetic Materials, 254-255 (2003), 495-497, doi:10.1016/S0304-8853(02)00848-X

${ }^{17}$ S. N. Kane, A. Gupta, Zs. Gercsi, F. Mazaleyrat, L. K. Varga, Mössbauer and magnetic studies of $\left(\mathrm{Fe}_{100-\mathrm{x}} \mathrm{Co}_{\mathrm{x}}\right)_{62} \mathrm{Nb}_{8} \mathrm{~B}_{30}(\mathrm{X}=0,33,50)$ alloys, Journal of Magnetism and Magnetic Materials, 292 (2005), 447-452, doi:10.1016/j.jmmm.2004.11.314

${ }^{18}$ H. Kronmüller, M. Fähnle, Micromagnetism and the microstructure of ferromagnetic solids, Cambridge University Press, Cambridge 2003

${ }^{19}$ H. Oukris, H. Lassri, E. H. Sayouty, J. M. Greneche, Magnetic and Mössbauer studies of amorphous Fe-Al-Er-B ribbons, Journal of Magnetism and Magnetic Materials, 260 (2003) 1-2, 23-27, doi:10.1016/S0304-8853(02)00059-8

${ }^{20}$ M. Nabiałek, P. Pietrusiewicz, K. Błoch, Influence of the production method of $\mathrm{Fe}_{61} \mathrm{Co}_{10} \mathrm{Y}_{8} \mathrm{~W}_{1} \mathrm{~B}_{20}$ amorphous alloy on the resulting microstructure and hyperfine field distribution, Journal of Alloys and Compounds, 628 (2015), 424-428, doi:10.1016/j.jallcom.2014.12.136 


\section{MATERIALI IN TEHNOLOGIJE/MATERIALS AND TECHNOLOGY (1967-2017) - 50 LET/50 YEARS}

\section{P. PIETRUSIEWICZ et al.: THE INFLUENCE OF AN ISOTHERMAL ANNEALING PROCESS ON THE STRUCTURE ...}

${ }^{21}$ P. Gupta, A. Gupta, A. Shukla, Tapas Ganguli, A. K. Sinha, G. Principi, A. Maddalena, Structural evolution and the kinetics of $\mathrm{Cu}$ clustering in the amorphous phase of $\mathrm{Fe}-\mathrm{Cu}-\mathrm{Nb}-\mathrm{Si}-\mathrm{B}$ alloy, Journal of Applied Physics, 110 (2011) 3, 033537, doi:10.1063/1.3622325

${ }^{22}$ A. Neuweiler, B. Hofmann, H. Kronmüller, Approach to magnetic saturation in nanocrystalline and amorphous $\mathrm{Fe}_{73.5} \mathrm{Cu}_{1} \mathrm{Nb}_{3} \mathrm{Si}_{13,5} \mathrm{~B}_{9}$ Journal of Magnetism and Magnetic Materials, 153 (1996), 28-34, doi:10.1016/0304-8853(95)00533-1

${ }^{23}$ M. Hirsher, R. Reisser, R. Würschum, H. E. Schaefer, H. H. Kronmüller, Magnetic after-effect and approach to ferromagnetic saturation in nanocrystalline iron, Journal of Magnetism and Magnetic Materials, 146 (1995), 117-122, doi:10.1016/0304-8853(94)01643-7

${ }^{24}$ T. Holstein, H. Primakoff, Field dependence of the intrinsic domain magnetization of a ferromagnet, Physical Review, 58 (1940), 1098-1113, doi:10.1103/PhysRev.58.1098

${ }^{25}$ N. Kaul, Magnetic properties of amorphous $(\mathrm{Fe}, \mathrm{Ni})_{80} \mathrm{~B}_{20},(\mathrm{Fe}$, $\mathrm{Ni})_{80} \mathrm{~B}_{19} \mathrm{Si}_{1}$, and $(\mathrm{Fe}, \mathrm{Ni})_{80} \mathrm{P}_{14} \mathrm{~B}_{6}$ alloys, IEEE Transaction on Magnetics, 17 (1981) 2, 1208-1215, doi:10.1109/TMAG.1981. 1061194

${ }^{26}$ B.W. Corb, R.C. O'Handley, N.J. Grant, Chemical bonding, magnetic moments, and local symmetry in transition-metal-metalloid alloys, Physical Review B, 27 (1983), 636-641, doi:10.1103/ PhysRevB.27.636
${ }^{27} \mathrm{~K}$. Błoch, Magnetic properties of the suction-cast bulk amorphous alloy: $\left(\mathrm{Fe}_{0.61} \mathrm{Co}_{0.10} \mathrm{Zr}_{0.025} \mathrm{Hf}_{0.025} \mathrm{Ti}_{0.02} \mathrm{~W}_{0.02} \mathrm{~B}_{0.20}\right)_{96} \mathrm{Y}_{4}$, Journal of Magnetism and Magnetic Materials, 390 (2015), 118-122, doi:10.1016/j.jmmm.2015.04.032

${ }^{28}$ M. Nabiałek, P. Pietrusiewicz, M. Dośpiał, M. Szota, J. Gondro, K. Gruszka, A. Dobrzańska-Danikiewicz, S. Walters, A. Bukowska, Influence of the cooling speed on the soft magnetic and mechanical properties of $\mathrm{Fe}_{61} \mathrm{Co}_{10} \mathrm{Y}_{8} \mathrm{~W}_{1} \mathrm{~B}_{20}$ amorphous alloy, Journal of Alloys and Compounds, 615 (2014), S56-S60, doi:10.1016/j.jallcom. 2013.12.236

${ }^{29}$ P. Pietrusiewicz, K. Błoch, J. Gondro, M. Nabiałek, M. Dośpiał, M. Szota, Magnetic relaxations in amorphous $\mathrm{Fe}_{61} \mathrm{Co}_{10} \mathrm{Y}_{8} \mathrm{Zr}_{1} \mathrm{~B}_{20}$ alloy, Acta Physica Polonica A, 126 (2014) 1, 106-107, doi:10.12693/ APhysPolA.126.106

${ }^{30}$ K. Błoch, M. Nabiałek, P. Pietrusiewicz, J. Gondro, M. Dośpiał, M Szota, K. Gruszka, Time and thermal stability of magnetic properties in $\mathrm{Fe}_{61} \mathrm{Co}_{10} \mathrm{Y}_{8} \mathrm{Nb}_{1} \mathrm{~B}_{20}$ bulk amorphous alloys, Acta Physica Polonica A, 126 (2014) 1, 108-109, doi:10.12693/APhysPolA.126.108

${ }^{31}$ P. Pietrusiewicz, K. Błoch, M. Nabiałek, S. Walters, Influence of $1 \%$ addition of $\mathrm{Nb}$ and $\mathrm{W}$ on the relaxation process in classical Fe-based amorphous alloys, Acta Physica Polonica A, 127 (2015) 2, 397-399, doi:10.12693/APhysPolA.127.397 